\title{
Glacial tectonic and flow structures in glaciogenic deposits: a cautionary note
}

\author{
C. P. GRAVENOR
}

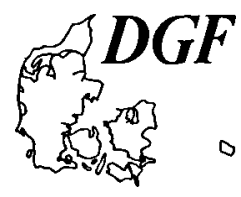

\begin{abstract}
Gravenor, C. P.: Glacial tectonic and flow structures in glaciogenic deposits: a cautionary note. Bull. geol. Soc. Denmark, vol. 34 pp. 3-11. Copenhagen, May, 30th, 1985. https://doi.org/10.37570/bgsd-1985-34-01

Large scale displacement and deformation of bedrock and associated glacial deposits can be produced by both glacial tectonics and debris flows. Large scale deformation of glacial deposits not associated with dis-placement of underlying strata can be produced by both glacial tectonics and ice-contact processes.

Smaller scale structures such as boudins, stringers of sand and silt and laminated diamictons can be produced by both glacial tectonics and flow processes.

Examples of both large and small scale structures produced by flow are presented to emphasize the need for adequate criteria to determine the origin of these structures.
\end{abstract}

C. P. Gravenor, Department of Geology, University of Windsor, Windsor, Ontario, Canada N9B 3P4. July 24th, 1984.

\section{Introduction}

The recognition that glaciers are capable of displacing and deforming underlying sediments is well documented by examples of large scale displacement of slabs of bedrock interlayered with glacial sediments from Europe and North America (e.g., Slater, 1927; Kupsch, 1962; Hansen, 1965; Moran, 1971; Banham, 1975).

Although several hypothesis have been developed to account for large scale displacement of underlying strata by glaciers, it is generally agreed that the phenomenon is confined to the margins of a glacier (e.g., Kupsch, 1962; Moran, 1971; Banham, 1975; Berthelsen, 1979, Moran et al, 1980). Hence, the directional aspects of large scale folds and faults produced by glacial tectonics provide an indication of the direction of glacial movement near the margin of glaciers and have been used extensively in some areas to determine ice-movement directions (e.g., Berthelsen, 1978; Aber, 1980). This is an acceptable practice provided that it is recognized that the surface expression of large scale ice-thrust features shows that the directions obtained from a single ice lobe may vary by as much as $80^{\circ}$ over a horizontal distance of some $6 \mathrm{~km}$ (Gravenor et al. 1960). This observation is reinforced by studies of glacially deformed bedrock in western New York State which show that the ice-movement di- rection derived from the axial traces of folds diverges by as much as 65 to 70 degrees from the regional ice-movement direction (Andrews, 1980). Hence, if these features are used to determine regional ice-movement directions, it is necessary to make a large number of measurements from the same glaciation and subject the results to vectorial analysis.

Over the past few years, it has been suggested that structures, such as folds, which do not show the displacement of underlying beds, and smaller structures such as laminations of sand, silt and chalk and boudinage-like structures, found in diamictons(ites) might be used as evidence of glacial tectonism (e.g., Berthelsen, 1979; Kruger, 1979). It is the purpose of this note to point out that similar structures, including the displacement of underlying strata, can be developed by flow unrelated to glacial tectonics and that there is a need to develop clear criteria to enable the field investigator to distinguish between structures created by glacial tectonism versus those resulting from mass movement. Such criteria are needed not only to decipher the glacial history of Quaternary glacial deposits but also to aid in determining the origin of similar structures found in many ancient glacial deposits.

Before proceeding to a discussion of structures found in glacial sediments, it should be pointed out that no attempt is made to provide a com- 
plete set of references as such a list would be almost endless.

\section{Folds and dislocated strata}

Folded and dislocated sediments may results from a wide variety of processes including glacial tectonics, glacial erosion and subsequent ice-contact deposition and by flow down a paleoslope. Where excellent exposures are available, such as those along coastal regions in Denmark (Hansen, 1965), or in England (Banham, 1975), or in inland areas, such as parts of Western Canada (Slater, 1927; Moran et al., 1980), there is usually no difficulty in assigning the folded and faulted sediments which contain rafts or "floes" of underlying material to a glacial-tectonic origin.

In other instances, however, the outcrops may be small and isolated and, under these conditions, the field geologists may be "conditioned" by his own experience to assign folded and faulted structures to one or another of the possible origins for such structures.

For example, in the coastal sections of southwest Nova Scotia, Canada, there is good evidence of deformation of bedrock by ice which moved in from the north (Grant, 1980). In the same general region (the Cape Cove section), isoclinically folded and faulted beds of sandy gravel are found. As the folding and faulting show movement to the south, Grant (1980, p. 30) has suggested that these beds originated as marine outwash and then were deformed by ice moving in a southerly direction which is consistent with the bedrock deformation. Yet none of these structures are, in themselves, proof of glacial tectonism (Boulton, 1972) and several geologists who visited this section in the Spring of 1980 were the opinion that the deposits are of icecontact origin. This is not the suggest that Grant is wrong and others correct but rather to point out that two quite different interpretations can be placed on the same field evidence.

In another setting, Martin $(1961,1964)$ has suggested that many folded structures found in the Late Paleozoic glaciogenic deposits of the Paraná Basin of Brazil were developed by icethrusting and used the directional aspects of the fold axes to determine ice-movement direction. Later, Rocha-Campos (1963, 1967) and Frakes

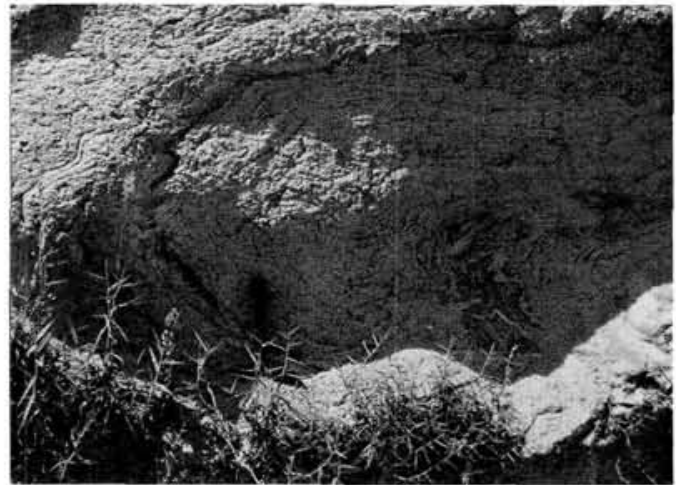

Fig. 1. Recumbent fold composed of diamictite interlayered with sandstone and fine gravel. Some of the beds of sandstone and fine gravel to the right of the hammer in the "centre" of the fold show evidence of shear. From field relationships, it is believed this fold resulted from ice-contact deposition (i.e., flow down an ice paleoslope). Location is Capivari, São Paulo State, Brazil.

and Crowell (1969) assigned many of the folded structures to flow down a paleoslope. Figs. 1 and 2 show two examples of folded structures in the Late Paleozoic glaciogenic deposits of Brazil which are composed of diamictites and stratified sands and fine gravels. Fig. 3 shows an example of rafted beds of sandstone surrounded by diamictite. From field relationships, the open recumbent fold shown in Fig. 1 may be of ice-contact origin and the isoclinal fold (Fig. 2) and the rafted beds of sandstone (Fig. 3 ) are probably the result of slump and rip-up of underlying strata by massive debris flows. The observation that the

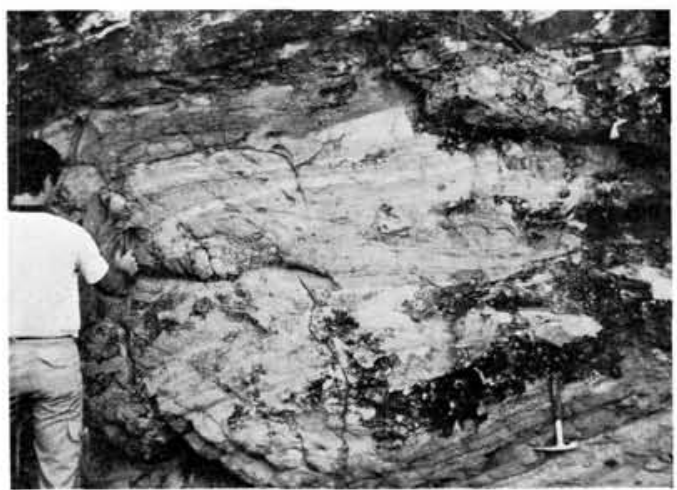

Fig. 2. Isoclinal folds composed of laminated sandstones with dropstones. Note the laminated diamictite marked by the hammer at bottom right of photograph. This bed of diamictite curls around the folded structure. Fold was developed by a debris flow down a paleoslope. Location is $\mathrm{Km} 87$ on BR 116 southwest of Curitiba, Brazil. 


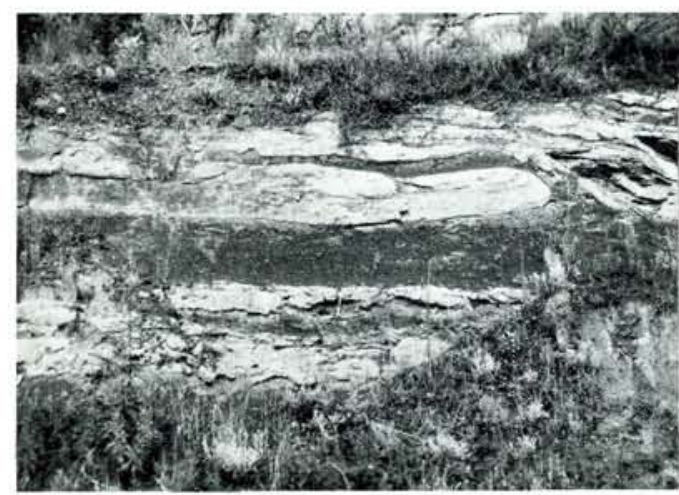

Fig. 3. Rafts of sandstone (white) surrounded by diamictite (dark-gray). Note the broken and deformed beds of sandstone at the upper right of photograph. The main bed of diamictite in centre of photograph is about $80 \mathrm{~cm}$ thick. Rafts are ripped up beds of sandstone which moved down a paleoslope with diamictite. Location is $15.5 \mathrm{~km}$ south of Rio do Sol. Santa Catarina State, Brazil.

folded structures show similar directions to those obtained by striae, roches moutonnées and grooved bedrock found on the margins of the Paraná Basin is probably due to the fact that both glaciers and debris flows tend to flow in the same direction down the paleoslope (Rocha-Campos, 1967).

Similarly, Spencer (1971) has assigned the large scale folds found within the glaciogenic sediments of the Late Precambrian of Scotland to a glacial-tectonic origin, whereas Schermerhorn $(1974,1975)$ has suggested the structures have resulted from mass movement into a subsiding basin. In part, Spencer (1971) based his conclusions on the similarity with the large scale folds found in the chalk rafts in the Pleistocene deposits of Norfolk, England, and the folded structures in the Paraná Basin of Brazil mentioned above and described by Martin (1964). Schermerhorn (1974, 1975), on the other hand, suggests that the presence of dolomite which is intercalated with and possibly laterally replaced by diamictite is incompatible with grounded ice conditions and that the folded structures must have resulted from movement of erosional rafts and detritus into a subsiding basin.

The next question which arises pertains to large scale folding and faulting in sands and gravels where there is no association with soft sediment, such as clay, diamicton or chalk to provide a weak zone along which slippage can take place. Although crushing and shearing of gravels and boulders in diamictons has been reported by a number of geologists (e.g., Kupsch, 1955; Boulton et al., 1974; Babcock et al., 1978), this crushing and shearing appears to be confined to a surface layer of up to a few meters in thickness and, in some cases, the original sedimentary structures have been left more or less intact (Kupsch, 1955). Babcock et al. (1978) suggest that although deformation of the soft sediments of the western plains of Canada is common, deformation of gravels overlain by glacial deposits is relatively rare. Further, it is important to note that there is apparently no large scale folding associated with the crushed gravels described by Babcock et al. (1978) and that the sheared zones may be associated with soft fine-grained material within the gravel. Similarly, Andrews (1980) has shown that breakage and faulting and folding of competent bedrock by glacial action must have taken place along pre-existing zones of weakness and is confined to the upper few meters of bedrock. Thus, it would appear that large scale folding and deformation in sands and gravels must be treated with caution as it is well known that such deformation can take place by ice-contact processes and downslope movement.

The above examples are given to illustrate the importance of developing criteria to distinguish sediment deformation by mass movement versus glacial tectonism. Glaciogenic deposits - up to a thousand or more meters in thickness - exist within the Precambrian, Ordovician and Late Paleozoic and Cenozoic basinal and terrestrial sediments. Hence, the need for adequate criteria to determine the origin of structures in glaciogenic sediments is not only of interest to students of Pleistocene glacial deposits but also to those who are attempting to derive acceptable explanations for the origin of an exceptionally large volume of glaciogenic sediments deposited over the past 2.4 billion years.

\section{Lamination and small structures in diamictons}

In many cases, sand, silt, and chalk stringers, boudinage-like structures and other small structures in diamictons can, by association with other evidence, be related to subglacial shear (Boulton 
et al., 1974; Berthelsen, 1979; and Krüger, 1979), and it has been suggested by Boulton et al. (1974) that sheared structures of this type are developed in ice-marginal areas where the frictional strength of the underlying material can be sufficiently low to allow shear to take place. If this is the case, then the attitude af sand, silt and chalk stringers and associated structures created by glacial tectonic shear is subject to the same constrictions in determining ice-movement direction as those mentioned above for large scale thrust features.

However, it must be kept in mind that the chalk stringers mentioned by Berthelsen (1979) and Krüger (1979) are very similar in appearance to the silt stringers described by Evenson et al. (1977) in subaqueous flows within the Catfish Creek Till. It should be noted that Evenson et al. $(1977$, p. 121,122$)$ have shown conclusively that some of the bands or stringers of silt are composed of broken up clasts of silt which they suggest originated from ponds on the surface of the adjacent ice or from deposition in the proglacial environment and subsequently redeposited by gravity movement. Indeed, a thin section of "subaquatic flow till" associated with the silt stringers and clasts clearly shows the presence of angualar particles of laminated silt which indicates that the silt was ripped up and intermixed with the diamicton flows (Evenson et al., 1977, Fig. 9). The description and explanation given by Evenson et al. (1977) strongly suggests that the silt originated as lumps of material which was broken up by interparticle shear which took place within, and possibly between, individual debris flows. The structure in the sand layers which occur between and interfinger with debris flows described by Evenson et al. (1977) were deposited initially as subaqueous outwash but, in some places, they appear to have been stretched out by frictional drag between, and possibly within, flows (Evenson et al., 1977, Fig. 11). In many ways, this suggested mechanism to explain the formation of wisps and stringers of silt and sand in diamicton flows approximates that given for similar deposits of flows and sorted material given by Boulton (1968, p. 408) and by implication by Gravenor et al. (1960, p. 13).

Along the north shore of Lake Erie, the Port Stanley Till lies stratigraphically above the Catfish Creek Till and represents deposits of the last ice to invade the Erie Basin (DeVries and Dremanis, 1960). As the Port Stanley Till was deposited under the same conditions as those described for the Catfish Creek Till by Evenson et al. (1977), similar structures should be present. Indeed, this is the case and, although I have not found good evidence of "hook" folds and sole structures, all of the other features described by Evenson et al. (1977) are present. In addition, however, I have found additional structures which add weight to the concept that the stringers of fine sand and silt originated on the surface of the retreating ice and were sheared out into various thicknesses of structureless stringers by the action of mass flow.

In Fig. 4 and Fig. 5, the main feature in the Port Stanley Till is a large block of sand surrounded by diamicton which contains elongated stringers of silt and clay. The centre of the block of sand is composed of a boulder of limestone and the bedding in the sand block shows evidence of contortion. Stringers and beds of silt and clay above and below the block of sand are curved around the block of sand and to the right of the sand block there is evidence of folding within the flow(s). As there is no evidence that the angular block of sand was carried in by rolling down a paleoslope, it would appear that it was carried in as part of a debris flow. Due to the poor heat conductivity of frozen material, it is reasoned that the block of sand was frozen and remained so during transport but the outer part thawed just prior to a halt in flow and the left (downstream)

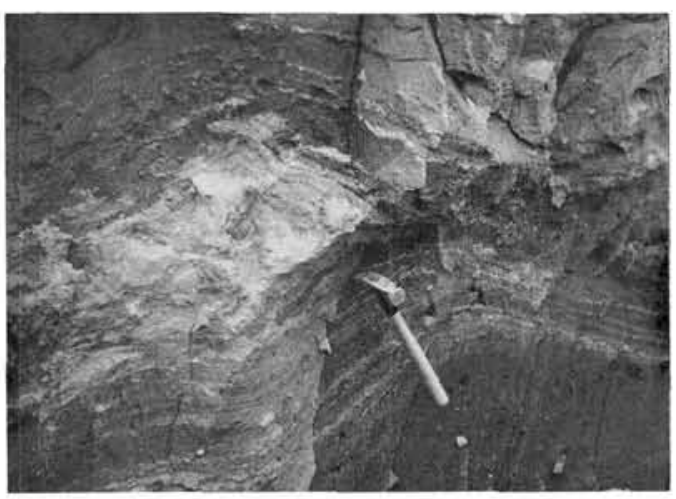

Fig. 4. Block of contorted sand with a limestone boulder in the centre surrounded by laminated and folded clayey diamicton. Note the similarity of the laminated diamicton with sheared slices of chalk in clay till described by Berthelsen (1979. Fig. 3). Port Stanley Till, Ruthven, Ontario, Canada. 


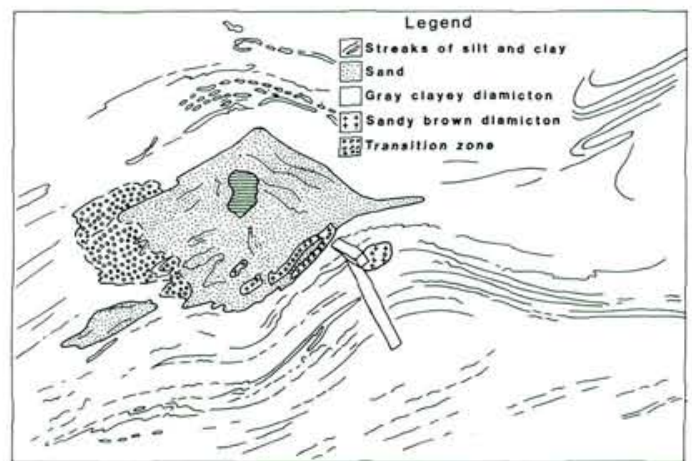

Fig. 5. Schematic sketch of Fig. 4. Note how the layers of silt, clay and diamictite "flow" around the block of sand. The smaller block of sand to the lower left of the main block may have been part of the main block. The folds at the upper right are marked by variation in clay content and not seen in the photograph. The sandy brown diamicton within the block of sand suggest that sand block originated in a pond on the ice and the sandy brown till flowed into the pond during deposition of the sand. Another block of sandy brown till is found to the right of the hammer and probably is the same as that found in the sand block. Compressional flow is shown by folding to the right of the sand block and crenulation in the silt layers below the sand block. Tensional flow is shown above the sand block where the silt layers have been stretched into a series of "pods".

side of the block was stretched out into the diamicton to form a "transition zone".

In Figs. 6 and 7, the main feature in the Port Stanley Till is a large fragment of sandy diamicton which contains many more pebbles than the surrounding Port Stanley Till and, in addition, contains fragments of clayey diamicton which is similar to the main body of the Port Stanley Till. The west (left) end of this till fragment has been stretched out into a folded structure and, similar

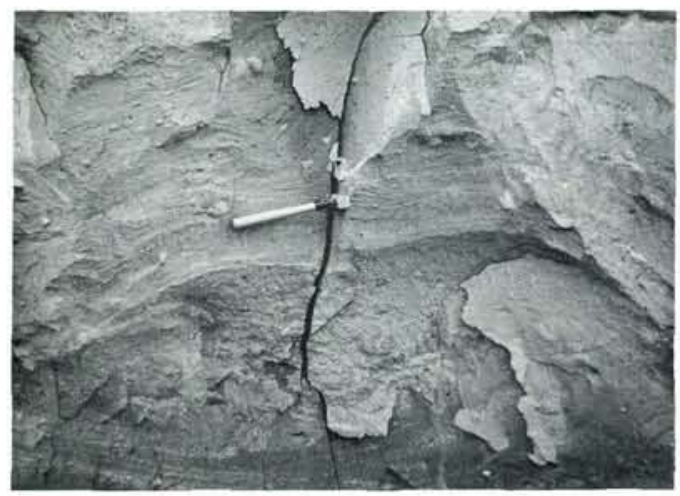

Fig. 6. Large contorted fragment of sandy till containing numerous pebbles and cobbles surrounded by laminated and folded clay till. Port Stanley Till, Ruthven, Ontario. Canada.

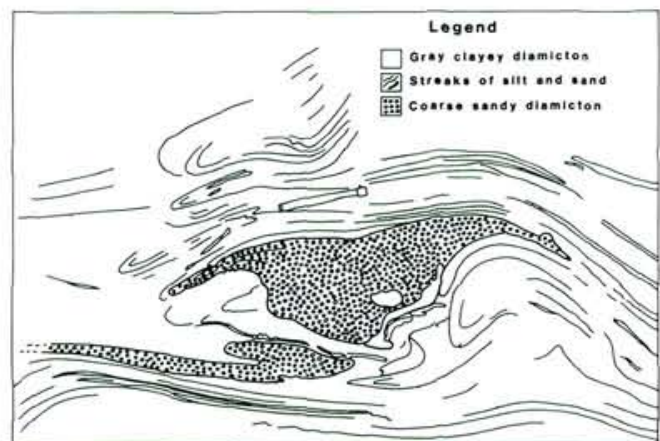

Fig. 7. Schematic sketch of Fig. 6. Note that the Port Stanley clay till flows around the fragment of coarse till. The white "streaks" are comprised primarily of silt except at the righthand side of the exposure where some of the laminae become more sandy. Note the fragments of clayey Port Stanley till caught up in the coarse sandy till. Below and to the left of large fragment of coarse till, there is a lense of coarse till similar in composition to the large fragment. The Port Stanley clay till shows excellent examples of isoclinally folded structures both above and below the fragment of coarse till.

to the block of sand, is surrounded by folded structures and beds and stringers of structureless fine sand and silt. The only difference between the block of sand and the fragment of till is that a small part of the coarse till fragment was soft and was deformed into a fold structure during flow.

Just below the large fragment of coarse till, there is a layer of coarse till which extends to the west in the original downslope direction. It is suggested that this elongate lense of coarse till was thawed to a greater degree than the large body of coarse till and was drawn out in the flow. In some repects, this layer of coarse till is similar to the layer of stone-rich diamicton described by Marcussen (1973, Fig. 9). Marcussen (1973, p. 225) suggests that the stone-rich layers may be due to stones sinking through a low vicosity flow till and collecting in discrete layers. An alternate explanation which does not conflict with the basic tenets of Marcussen's argument is that the stone-rich layers originated as bodies of winnowed stonerich material on the ice surface and moved into the flow environment either as discrete flows or as larger fragments of coarse debris which thawed within the flow and were drawn out in the flows. This latter explanation would also fit with observations by Marcussen (1973, p. 224-225) that, in the same section, lumps of till are found in sorted sands. As suggested by Marcussen (1973, p. 225), these till bodies probably ori- 
ginated on the surface of the ice and fell into a basin in which sand was being deposited. This explanation for till bodies in stratified debris is very similar to that given by Gravenor et al. (1960, p. 13) and fits with the overall model for the origin of some supraglacial and proglacial flow deposits.

In the Port Stanley Till there is no evidence that either the block of sand with the enclosed boulder or the large fragment of coarse till with enclosed pods of clayey diamicton were sheared up from below. It is suggested that they must have originated from the surface of the retreating ice and were carried into their present position in a debris flow. The configuration of the stringers of sand and silt above and below these foreign bodies suggests flow around the bodies with the possibility that part of the deformation below the bodies may have been caused by differential compaction. This would suggest that the stringers and beds of structureless sand and silt are all part of the same debris flow and not individual flows separated by the sand and silt bodies. In this context, however, evidence for a number of flows is presented by other evidence, such as ripplemarked and laminated sand lenses which interfinger with the debris flows similar to those described by Evenson et al. (1977).

If such large bodies of material were carried in with the flows, then it is reasoned that smaller bodies of sand and other materials were carried in with the flows, melted and the particles

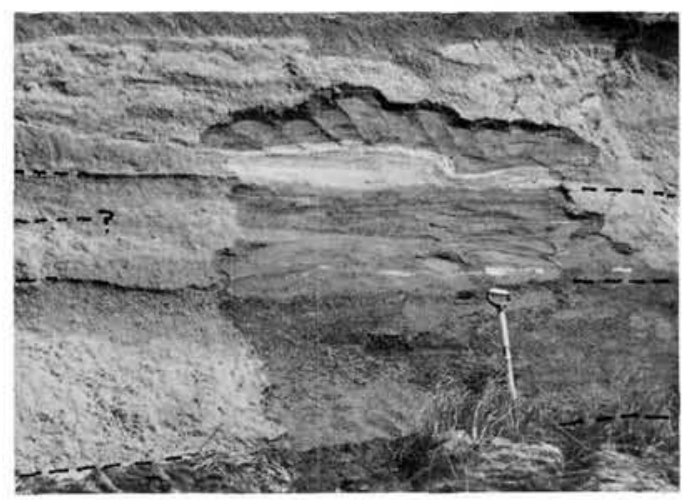

Fig. 8. Debris flows containing streaks, lenses and interflow alluvial sands. There are a minimum of 4 flows and possibly as many as 6 in this section. The flows coarsen upwards and the lower two flows are quite clayey in character. Note the overturned layer of alluvial sand and stretched out and folded fragment of sand (just above shovel handle), all of which indicate flow from left to right (north to south). Location is near Lyngby, Jutland, Denmark.

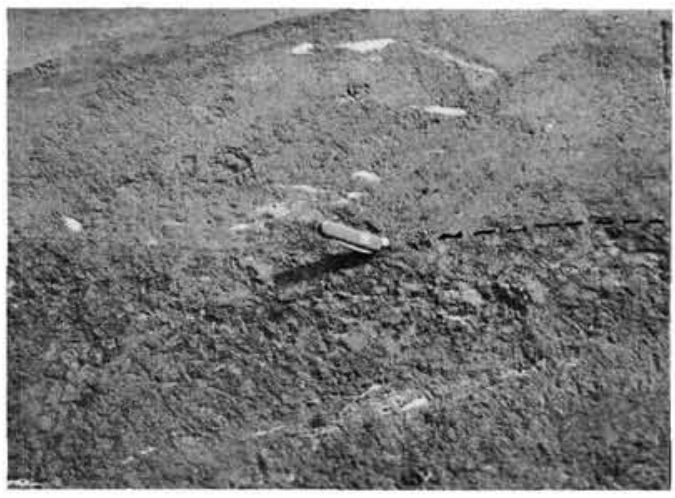

Fig. 9. Contact between two flows (marked by knife and dotted line). The lower flow is noticeable more rich in clay than the upper flow. At the left side of the photo, there is a sand "peble" which shows no evidence of disturbance. Other fragments of white sand in both flows have been stretched out in the flows. Location is Lyngby, Jutland, Denmark.

stretched out along flow lines in the debris flow. In some places, these stringers were under subsequent compression and formed crenulated lamination and, in other places, under tension and were broken up into a series of isolated pods. Examples of both compression and extension were shown above and below the sand block (Figs. 4 and 5). As indicated above, this evidence adds weight to the observations and interpretation given to similar flows in the Catfish Creek Till described by Evenson et al. (1977). Although Gibbard (1980) has challenged the model devised by Evenson et al. (1977), it appears that Gibbard

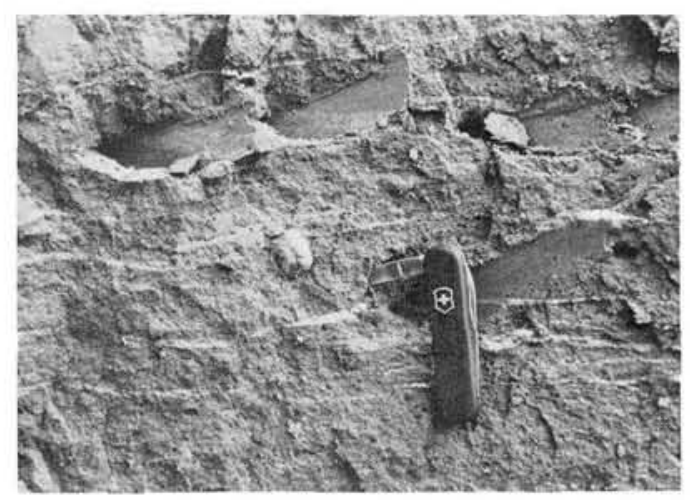

Fig. 10. Sandy debris flow showing laminated appearance as a result of sand "pebbles" which have been stretched out in the direction of flow. Note the pebble to the left of the knife. Pebbles are numerous in the flows but difficult to see because they are generally coated with sand or clay. Location is Lyngby, Jutland, Denmark. 


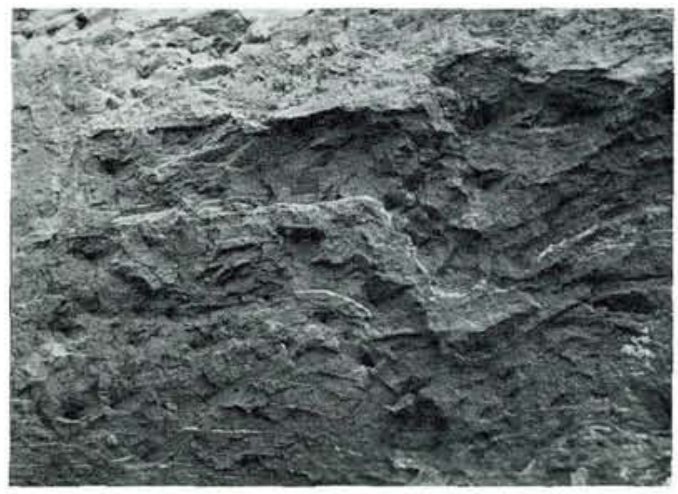

Fig. 11. Sandy debris flow which shows lamination caused by streaks of sand which have been stretched out and overturned. Overturning indicates flow from left to right (north to south). Thicker intraflow contorted alluvial sands are found at the upper left-hand corner of photograph. Scale is given by knife in centre of photograph. Location is Lyngby, Jutland, Denmark.

did not examine the same part of the section as Evenson et al. (1977). (Dreimanis, personal communication).

This suggested sequence of events is well illustrated in a series of at least four superposed debris flows found near Nr. Lyngby in northwest Jutland, Denmark. The flows are found at the south end of the series of glacial-tectonic thrust sheets which make up Lønstrup Klint (Hansen, 1965) but are flat-lying and unrelated to the glacial-tectonic features. The individual flows are recognized primarily on the basis of texture (which varies from clayey near the base to sandy near the top) and colour (Fig. 8). It is of interest

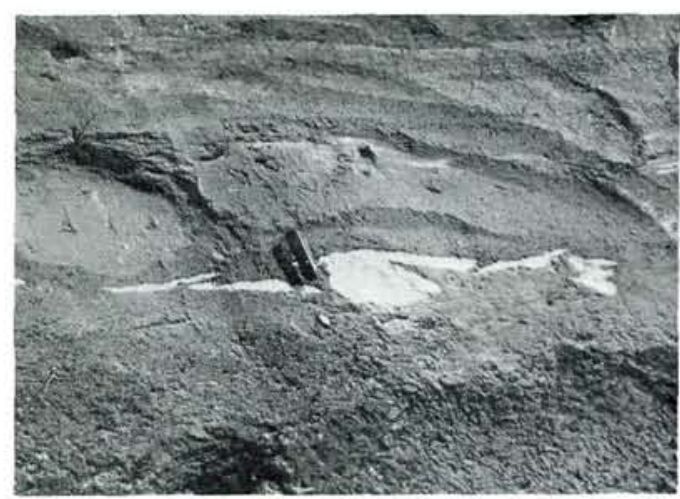

Fig. 12. Sandy debris flow which contains fragments of white sand which are stretched out. Just to the right of the knife, the top of a sand "pebble" has been stretched out to the right (south) to form an "anvil" structure. Location is Lyngby, Jutland, Denmark.

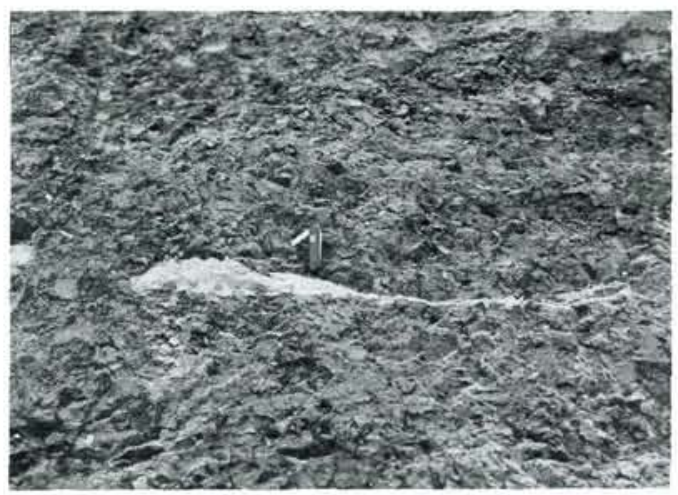

Fig. 13. Clay rich debris flow which shows a fragment of sand which has been streamlined by flow to the right (south). This streamlined form is very similar to "torpedo"structures described by Berthelsen (1978, Fig. 7). Location is Lyngby, Jutland, Denmark.

to note that no basal till has been found at the base of the flows and they rest directly and without disturbance on underlying upthrust sands and clays. However, basal till exists to the north of this section (Hansen, 1965) in the same stratigraphic position as the flows and the possibility exists that the flows are the ablation counterpart of the basal till and they flowed toward the south from the retreating ice. The unique composition of the flows is directly related to the fact that the ice was passing over and eroding the upthrust sands and clays.

The most striking feature of these flows is the presence of "pebbles", streamlined lenses and stringers composed of white sand (Figs. 9, 10, 11, 12 and 13). The pockets or stringers of sand are frequently elongated and folded in a manner which shows movement north to south. Excavation into the flows shows that the pockets and stringers of sand have little lateral continuity. Although most of the pockets of sand flowed parallel to the base of individual flows, many show evidence of folding which indicate flow to the south.

In some places, thicker layers of alluvial sand are present between flows and these sand beds frequently show folding towards the south (Fig. $8)$. These sand beds are similar in many respects to those described by Evenson et al. (1977).

It is suggested that the elongated and streamlined Ineses and tringers of white sand all originated as "pebbles" or irregular fragments of sand which were carried along and shaped within the debris flows. In many respects, these stream- 
lined and elongated lenses of sand resemble the "torpedo" structures described by Berthelsen (1978, Fig. 7) which he assigned to a glacial tectonic origin. The original pebbles of sand must have been frozen and melted after they were encased in the diamictite. At this stage, the internal strength of the sand would be very low and stretching and shaping was readily accomplished within the debris flows. Similar small scale stretched-out boudinage-like lenses of sand are commonly found in large scale subaqueous glaciogenic debris flows of the Paraná Basin (Fig. 14) and in slump structures within pebbly mudstone in California (Crowell, 1957, p. 999).

Therefore, it is suggested that in the case of the Lyngby flows, the fragments of frozen sand originated in ponds and streams on the surface of glaciers located to the north of the flows and fragments of the sand were incorporated in the debris flows in much the same way as the broken fragments of silt were incorporated in the debris flows and intercalated beds described by Evenson et al. (1977).

The problems of determining the origin of small scale structures which lead to a "laminated" structure in diamictite is well illustrated by the comments in two recent papers. Berthelsen $(1978$, p. 32) suggests that, in general, it is not difficult to distinguish glaciodynamic from subsequent structures formed under the influence of gravity alone and goes on to state, "Marcussen (1973, Fig. 12) thus describes flow till structures

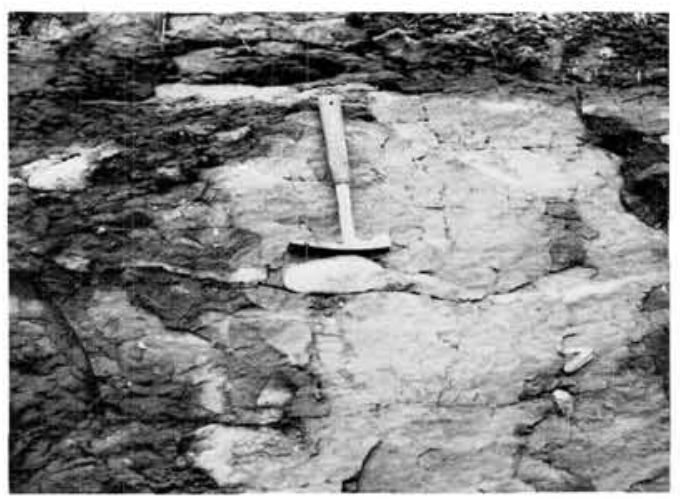

Fig. 14. Boudinage structures and stretched out lenses of sandstone in Late Paleozoic diamictite. These small scale structures are found within massive debris flows. Note the similarity of this boudin and stretched lenses of sandstone with those assigned to shear by Berthelsen (1979, Fig. 10). Location is $6 \mathrm{~km}$ south of Rio do Sol, Santa Catarina State, Brazil. which the present author would rather classify as typical glaciodynamic structures ..." (italics mine). In a more recent paper, Hicock et al. (1981) make the following statement, "The flow tills are most easily recognizable by their concentric layering around the noses of fold-like lobate forms (Figs. 3, 5), which represent their resting position upon loss of inertia during travel. Boulton (1968) and Marcussen (1973) have described similar, terrestrial flow tills in Spitsbergen and Denmark, respectively". This combination of comments, along with the above observations made on flows in northern Jutland, southwestern Ontario and in ancient glacial deposits, would suggest that products of glacial tectonism and those of gravity flow are difficult to differentiate with our present state of knowledge.

\section{Conclusions}

Structures, such as folds, faults and streamlined and elongated lenses and stringers of soft material are commonly found in ice-contact deposits and debris flows which closely resemble those ascribed to glacial tectonic processes. This is not to cast doubt on structural features which have been assigned to one origin or the other rather to point out the need to develop criteria that the field geologist can use to determine the origin of certain of these structural features. Most certainly, the presence of crushed rock and, in most cases, large scale displacement of underlying strata interlayered with glacial materials provide good evidence of glacial tectonics. But problems can arise in attempting to assign structures in diamictites to a specific origin in the absence of solid criteria. It is evident as stated by Berthelsen (1978) that more structural studies are needed to delineate criteria to distinguish structures resulting from flow versus those developed by glacial tectonics. In a discussion of techniques to differentiate sedimentary from tectonic structures, Hobbs et al. (1976) list some 10 criteria but of these they state that only three are definitive. However, except under unusual circumstances, none of these three are of use to the student of glacial geology. Thus, the task will not be easy but, nevertheless, necessary if glacial geologists 
wish to use structures found in glaciogenic deposits for a variety of purposes.

Acknowledgements. I would like to thank Ib Marcussen and the Geological Survey of Denmark for providing assistance and guidance in that portion of the study made in Denmark. The examples from Brazil were taken from a joint study underway on the diamictites of the Paraná Basin with A. C. RochaCampos. The study was made possibly by a grant in aid of research from the Natural Science and Engineering Research Council of Canada.

\section{Dansk sammendrag}

Forfatteren giver en række eksempler på strukturer, især folder og strømlineformede legemer, der dels kan tolkes som resultat af glacialtektonisk påvirkning og dels som resultat af flydebevagelser ved almindelig gravitativ omlejring. En og samme struktur kan af forskellige observatører tolkes meget forskelligt, hvorfor det konkluderes, at behovet for kriterier til at adskille tektoniske strukturer fra sedimentære strukturer er voksende.

\section{References}

Aber, J. S., 1980: Kineto-stratigraphy of Hvideklint, Møn, Denmark and its regional significance. Bull. geol. soc. Denmark, 28, pp. 81-93.

Andrews, D. E., 1980: Glacially thrust bedrock - An indication of Late Wisconsin climate in western New York State. Geology, 8, pp. 97-101.

Babcock, E. A., Fenton, M. M. and Andriashek, L. D., 1978: Shear phenomena in ice-thrust gravels, central Alberta. Can. Journ. Earth Sci., 15, pp. 277-283.

Banham, P. H., 1975: Glacio-tectonic structures: a general discussion with particular reference to the contorted drift of Norfolk. In Ice Ages: Ancient and Modern. Wright, A. E. and Moseley, F., (eds.). Seel House Press, Liverpool, U.K., pp. 69-94.

Bethelsen, A., 1979: Recumbent folds and boudinage structures formed by subglacial shear: an example of gravity tectonics. Geologie en Mijnhouw, 58, pp. 253-260.

Berthelsen, A., 1978: The methodology of kineto-stratigraphy as applied to glacial geology. Bull. geol. Soc. Denmark, 27, pp. 25-28.

Boulton, G. S., Dent, D. L. and Morris, E. M., 1974: Subglacial shearing and crushing and the role of water pressures in tills from south-east Iceland. Geografiska Annaler, 56 , pp. 135-145.

Boulton, G. S., 1972: Modern Arctic glaciers as depositional models for former ice sheets. Jour. Geol. Soc. London, 128, pp. 361-393.

Boulton, G. S., 1968: Flow tills and related deposits on some Vestspitsbergen glaciers. Jour. Glaciology, 7, pp. 391-412.

Crowell, J. C., 1957: Origin of pebbly mudstone. Bull. Geol. Soc. America, 68, pp. 993-1010.
DeVries, H. and Dreimanis, A., 1960: Finite radiocarbon dates of the Port Talbot interstadial deposits in southern Ontario. Science 131, 1738-1739.

Evenson, E. B., Dreimanis, A. and Newsome, J. W., 1977: Subaquatic flow tills: a new interpretation for the genesis of some laminated till deposits. Boreas, 6, pp. 115-133.

Frakes, L. A. and Crowell, J. C., 1969: Late Paleozoic Glaciation: I, South America. Bull. Geol. Soc. America, 80, pp. 1007-1042.

Gibbard, P., 1980: The origin of stratified Catfish Creek Till by basal melting. Boreas, 9, pp. 71-85.

Grant, D. R., 1980: Quaternary stratigraphy of southwestern Nova Scotia: glacial events and sea-level changes. Geol. Ass. Canada, Field Trip Guidebook, Trip 9,63 pp.

Gravenor, C. P., Green, R. and Godfrey, J. D., 1960: Air photographs of Alberta. Res. Coun. Canada, Bull. 5, 37 pp.

Hansen, S., 1965: The Quaternary of Denmark in The Quaternary Vol. 1. Rankama, K., (ed.). Interscience, New York, 1-90.

Hobbs, B. E., Means, W. D. and Williams, P.'F., 1976: An outline of structural geology. John Wiley and Sons, New York, 571 pp.

Krüger, J., 1979: Structures and textures in till indicating subglacial deposition. Boreas, 8, pp. 323-340.

Kupsch, W. O., 1962: Ice thrust ridges in western Canada. Jour. Geol. 45, 582-594.

Kupsch, W. O., 1955: Drumlins with jointed boulders near Dollard, Saskatchewan. Bull. Geol. Soc. America, 66, pp. 327-337.

Marcussen, I., 1973: Studies on flow till in Denmark. Boreas, 2 , pp. 213-231.

Martin, H., 1964: The directions of flow of the Itarare Ice Sheets in the Paraná Basin, Brazil. Boletim Paranaense de Geografia, 25-77.

Martin, H., 1961: The hypothesis of continental drift in the light of recent advances of geological knowledge in Brazil and in South-West Africa. Geol. Soc. South Africa, Trans., Annexure, 64, Alex L. du Toit Memorial Lectures, No. 7, 1-147.

Moran, S. R., 1971: Glaciotectonic structures in drift, In Till: $A$ Symposium. Goldthwait, R. P., (ed.). Ohio State University Press, 127-148.

Moran, S. R., Clayton, L., LeB. Hooke, R., Fenton, M. M. and Andriashek, L. D., 1980: Glacier-bed landforms of the Prairie Region of North America. Jour. Glaciology, 25 , pp. 457-476-

Rocha-Campos, A. C., 1967: The Tubarão Group in the Brazilian portion of the Paraná Basin In Problems in Brazilian Gondwana Geology. Bigarella, J. J., Becker, R. D. and Pinto, I. D., (eds.). Roesner, Curitiba, Brazil, 27-102.

Rocha-Campos, A. C., 1963: Deformaçóes penecontemporaneas em sedimentos gláciolacustres do Grupo Turbaróa. Boletim Soc. Brasil Geologica, 12, pp. 49-56.

Schermerhorn, L. J. G., 1975: Tectonic framework of Late Precambrian supposed glacials In Ice Ages: Ancient and Modern. Wright, A. E. and Moseley, F., (eds.). Seel House Press, Liverpool, U.K., 241-274.

Schermerhorn, L. J. G., 1974: Late Precambrian mixtites: glacial and/or nonglacial? Amer. Jour. Sci., 274, pp. 673-824.

Slater, G., 1927: Structure of the Mud Buttes and Tit Hills in Alberta. Geol. Soc. America Bull., 38, pp. 721-730.

Spencer, A. M., 1971: Late Pre-Cambrian glaciation in Scotland. Geol. Soc. London. Memoir No. 6, 98 pp. 